\title{
Aggravated Sentencing: Blakely v. Washington
}

Jon Wool

Don Stemen

Loyola University Chicago, dstemen@luc.edu

Follow this and additional works at: https://ecommons.luc.edu/criminaljustice_facpubs

Part of the Criminology and Criminal Justice Commons

\section{Recommended Citation}

Wool, J and D Stemen. "Aggravated Sentencing: Blakely v. Washington." Policy and Practice Review, 2004.

This Article is brought to you for free and open access by the Faculty Publications and Other Works by Department at Loyola eCommons. It has been accepted for inclusion in Criminal Justice \& Criminology: Faculty Publications \& Other Works by an authorized administrator of Loyola eCommons. For more information, please contact ecommons@luc.edu.

\section{(c) $($ () $\ominus$}

This work is licensed under a Creative Commons Attribution-Noncommercial-No Derivative Works 3.0 License. (c) VERA Institute of Justice, 2004. 


\section{Vera Institute of Justice \\ State Sentencing and Corrections}

Policy and Practice Review August 2004

\section{Aggravated Sentencing: Blakely v. Washington}

\section{Practical Implications for State Sentencing Systems}

\author{
Jon Wool and Don Stemen
}

At the close of its 2003-2004 term, the United States Supreme Court roiled many states' criminal justice systems when it struck down Washington's sentencing guidelines scheme.

In Blakely v. Washington the Court ruled that a judge may not increase a defendant's penalty beyond that which would be available "solely on the basis of the facts reflected in the jury verdict or admitted by the defendant." Put another way, under Blakely, when the law establishes an effective maximum sentence for an offense, the Sixth Amendment's right to trial by jury prohibits a judge from imposing a longer sentence if it is based on a fact-other than prior conviction-determined by the judge. Any such fact must be proved to a jury beyond a reasonable doubt if not admitted by the defendant.

The ruling, which invalidated the provisions of Washington's guidelines system that allow a judge to make factual findings and then impose a penalty beyond a recommended standard range of sentences, has wide implications. In her dissent, Justice O'Connor identified nine other states whose sentencing regimes are cast into doubt under Blakely. Our analysis suggests that there may be many more. $^{2}$

Five states-Kansas, Minnesota, North Carolina, Oregon, and Tennessee-employ presumptive sentencing guidelines systems that enable judges to enhance sentences by finding
This is the inaugural issue of a new series that will focus on the Supreme Court's powerful, yet profoundly disrupting, decision in Blakely v. Washington. Over the next six months, we will seek to provide timely and helpful analysis of Blakely's reach, offer practical advice to state lawmakers needing to realign their systems, and report on state reactions to the ruling. In sum, we hope to help decision makers find appropriate answers (many of which already exist and some of which are working in practice)—and perhaps even the opportunity for positive change-amid the uncertainty and apprehension that the Court has caused.

In this first report, we look to answer two big questions: Which states' sentencing systems are affected by Blakely? and What responses are available to legislators and other policymakers? The first section assesses states according to the characteristics of their sentencing systems and their susceptibility to Blakely. The second section examines possible solutions, including the use of jury factfinding for states seeking to retain enhanced penalties and how voluntary guidelines systems may be inoculated against Blakely ills by changing the ways in which judges use or report deviations from their guidelines.

The next publication in the series, the companion piece Legal Considerations for State Sentencing Systems, will provide a more detailed examination of the legal issues raised in Blakely and prior decisions of the Court and discusses the implications for sentencing provisions apart from those in structured sentencing regimes.

Publications are only part of Vera's Blakely response. We are helping state officials manage the implications of the ruling, both through onsite work in capitals and by bringing state leaders together to learn from national experts and each other about promising responses. To learn more about Vera's state work, please contact me at (212) 376-3073, dwilhelm@vera.org, or visit Vera's website at www.vera.org/ssc.

Daniel F. Wilhelm

Director, State Sentencing and Corrections Program 
aggravating facts, as does the Washington system addressed by the Court. At least eight additional non-guidelines statesAlaska, Arizona, California, Colorado, Indiana, New Jersey, New Mexico, and Ohio_employ functionally equivalent presumptive sentencing systems. The systems in this core group of I3 states appear to be fundamentally affected by the Blakely decision. ${ }^{3}$

\section{Glossary}

The following definitions reflect their most common usage and their usage in this report.

Structured sentencing system: a system providing some form of recommended sentences within statutory sentence ranges.

Sentencing guidelines system: procedures to guide sentencing decisions and a system of multiple, recommended sentences based generally on a calculation of the severity of the offense committed and the criminal history of the offender.

Presumptive sentencing guidelines: sentencing guidelines that require a judge to impose the recommended (presumptive) sentence or one within a recommended range, or provide justification for imposing a different sentence.

Voluntary sentencing guidelines: sentencing guidelines that do not require a judge to impose a recommended sentence, but may require the judge to provide justification for imposing a different sentence.

Presumptive sentencing: a system of recommended (presumptive) sentences, based solely on the offense or offense class, that a judge must impose or provide justification for imposing a different sentence.

Effective maximum sentence: the maximum sentence authorized for an offense based solely on the facts reflected in the jury verdict or admitted by the defendant.

Enhanced sentence: a sentence longer than the effective maximum sentence.

Determinate sentencing system: a system in which there is no discretionary releasing authority and an offender may be released from prison only after expiration of the sentence imposed (less available good or earned time).

Indeterminate sentencing system: a system in which a discretionary releasing authority, such as a parole board, may release an offender from prison prior to expiration of the sentence imposed. It may also, but need not, allow judges to impose a sentence range (such as, three-to-six years) rather than a specific period of time to be served.
Although Justice O'Connor may have understated the number of states affected by the Court's ruling, the situation may not be as dire as her conclusion that "[o]ver 20 years of sentencing reform are all but lost." It is true that affected states will have to amend their sentencing structures... But that reality is tempered by the fact that in many states, unlike the federal system, judicial factfinding is used in only a small fraction of cases.

The fallout may also envelop six other states-Arkansas, Delaware, Maryland, Rhode Island, ${ }^{4}$ Utah, and Virginiaemploying voluntary sentencing guidelines systems that nonetheless require a court to apply a suggested sentence range and provide justification for any sentence above that recommended by the range. Depending on how future court decisions define the scope of Blakely, it is also possible that two indeterminate sentencing states-Michigan and Pennsylvania - that employ presumptive sentencing guidelines systems may run afoul of the ruling. Finally, Blakely has implications for other state sentencing provisions beyond these $2 \mathrm{I}$ with structured sentencing systems. ${ }^{5}$ Every statute that provides for an enhanced penalty beyond that authorized solely by the jury's verdict must be examined to determine whether it is based on facts-other than prior conviction-determined by a judge. Such statutes include those that allow additional punishment upon a judge's finding that the defendant was on parole at the time of the offense, that the crime was committed for compensation, or that the victim was of a certain age. We will discuss these implications in a companion report, Legal Considerations for State Sentencing Systems.

Although Justice O'Connor may have understated the number of states affected by the Court's ruling, the situation may not be as dire as her conclusion that "[o]ver 20 years of sentencing reform are all but lost." ${ }^{\prime 6}$ It is true that affected states will have to amend their sentencing structures in large or small ways. But that reality is tempered by the fact that in many states, unlike the federal system, judicial fact-finding is used in only a small fraction of cases and thus is easier to avoid while states are constructing responses. Moreover, there are ways to cure Blakely ills, and examples exist of constitutionally-sound solutions that largely preserve the goals that drove states to enact 
structured sentencing systems. As Justice Scalia states for the Court, "we are not ... find[ing] determinate sentencing schemes unconstitutional. ... Nothing we have said impugns [the] salutary objectives" of "proportionality to the gravity of the offense and parity among defendants" that prompted Washington's guidelines system. ${ }^{7}$

That having been said, states' ability to limit judicial discretion to achieve these and other goals is now significantly constrained. It is perhaps ironic that the Court has found that the Sixth Amendment, with its jury guarantee as a bulwark against state power, actually limits attempts to reign in judicial authority through structured sentencing. On the one hand, it is hard to argue with the Court's view of the centrality of both the right to be tried by a jury of one's peers and the application of the highest standard of proof beyond a reasonable doubt; indeed the dissenting justices do not make much of an effort. On the other hand, it is the Court's insistence on drawing a "bright-line" formulation to protect these rights, one that establishes a firm constitutional line rather than allowing legislative and judicial flexibility, that is precipitating the present upheaval. ${ }^{8}$

\section{The Impact of Blakely on State Systems}

At the end of the day, Blakely's reach largely will be determined by courts in the states. They will determine the force and effect of their sentencing rules and whether certain provisions violate Blakely. And they will determine whether simply the offending provisions are affected or whether a state's entire structured sentencing scheme is void. It is likely that results will differ state to state based on distinctions in sentencing structures, differing interpretations of the Court's ruling, and the degree to which pragmatic concerns about systemic impact influence judgment. It will take a few years for the ultimate nature and scope of Blakely's impact to be known, but this much we know for certain: its potential to reshape sentencing in the United States is profound, as we discuss below.

\section{Presumptive sentencing guidelines systems}

It is evident that the four other states (not including Kansas, which is discussed below) with presumptive sentencing guidelines systems-Minnesota, North Carolina, Oregon, and Tennessee - will be affected by the decision to the same extent as Washington. In each of these states, guidelines establish a range for an offense that sets the maximum sentence a judge may impose based on the jury's verdict. A judge may impose a sentence above the maximum in the range only when the judge makes a finding of aggravating factors.

\section{Presumptive sentencing guidelines systems: fundamentally affected by Blakely \\ Minnesota \\ North Carolina \\ Oregon \\ Tennessee \\ Washington}

\section{Presumptive (non-guidelines) sentencing systems:}

\section{fundamentally affected by Blakely}

Alaska

Arizona

California

Colorado

Indiana

New Jersey

New Mexico

Ohio

\section{Voluntary sentencing systems: possibly affected by Blakely \\ Arkansas \\ Delaware \\ Maryland \\ Rhode Island \\ Utah \\ Virginia}

\section{Voluntary sentencing systems: not affected by Blakely District of Columbia \\ Louisiana \\ Missouri \\ Wisconsin}

\section{Presumptive sentencing guidelines in indeterminate systems: possibly affected by Blakely \\ Michigan \\ Pennsylvania}

Washington, for its part, prescribes a presumed sentence range, the "standard range," within the broader statutory sentence range for each offense. The judge must impose a definite term within this standard range, but on finding an "aggravating factor" the judge may impose an "exceptional sentence" beyond the standard range but lower than the 
statutory maximum. When an exceptional sentence is based on such an aggravating factor, the judge must articulate, for the record, facts to support that decision. ${ }^{9}$ The guidelines systems in Minnesota and Oregon are nearly identical in structure to Washington. Those in North Carolina and Tennessee are different, but not in ways relevant to the ruling in Blakely.

Unlike other systems, North Carolina's guidelines are "mandatory" in that they require a judge in every case to impose a sentence within the designated cell of a sentencing guidelines grid. ${ }^{10}$ Thus, judges in North Carolina cannot impose a sentence above those recommended within a guidelines cell, as judges can in Washington. However, the North Carolina guidelines set mitigated, presumptive, and aggravated ranges within each cell. The court must impose a sentence within the presumptive range unless the judge finds aggravating factors by a preponderance of the evidence. Only then may the judge impose a sentence within the aggravated range. In this sense, a sentence in the aggravated range in North Carolina is an enhanced sentence, equivalent to an "exceptional sentence" under the Washington guidelines.

\section{Blakely's reach largely will be determined \\ by courts in the states. They will \\ determine whether certain provisions of a state's sentencing rules violate Blakely.}

In Tennessee, on the other hand, guidelines establish sentence ranges with single-term "presumptive sentences" within those ranges. For the most serious class of felonies, the presumptive sentence is the midpoint in the guidelines range; for lesser felonies, the presumptive sentence is the minimum term in the guidelines range. The court must impose the presumptive sentence unless the judge states on the record a finding of an "enhancement factor." In such instances the judge may impose a sentence up to the maximum in the guidelines range for the offense. ${ }^{11}$ Thus, Tennessee's guidelines differ from those in Washington in that the presumptive sentence is a single term of years rather than a range of sentences. This single term is the effective maximum for an offense because a sentence above this term (even within the guidelines range) requires a finding of additional "enhancement factors."

All of these states share the same fundamental problem: a jury's verdict, or a defendant's guilty plea, only authorizes a sentence to the presumptive maximum sentence or within the presumptive range. An enhanced sentence requires a finding of facts by the judge - the very thing the Supreme Court ruled violates the Sixth Amendment right to trial by jury.

Kansas employs a presumptive sentencing guidelines system similar to Washington's. However, Kansas's system is not generally implicated by Blakely because it has amended its statutes to require that a jury find any fact that forms the basis of an enhanced sentence. Kansas acted in response to the only state court decision that struck down its guidelines system for the reasons ultimately determined by the Court in Blakely. ${ }^{12}$ As we discuss below, the Kansas model represents one solution to the problem in these

states' systems. ${ }^{13}$

\section{Presumptive (non-guidelines) sentencing systems}

At least eight states that do not formally employ guidelinesAlaska, Arizona, California, Colorado, Indiana, New Jersey, New Mexico, and Ohio—nonetheless employ presumptive sentences and require judges to provide justification when they deviate from those sentences. Although these states' systems lack the multiple ranges of sentencing guidelines systems, they are comprehensively structured and functionally equivalent to guidelines, at least for Sixth Amendment purposes. In all of these-often referred to as presumptive sentencing or determinate sentencing systems-statutes set a single presumptive sentence or range of sentences for each offense within the statutory range. The judge must impose that presumptive sentence or one within the presumptive range and may impose a higher term only after finding aggravating factors.

New Mexico is typical. In New Mexico, statutes set a single-term "basic sentence of imprisonment" for each offense. For a first degree felony, for example, the basic sentence is I8 years; for a second degree felony, it is nine years. The appropriate basic sentence must be imposed unless the court alters it based on aggravating or mitigating circumstances. When the judge finds any "aggravating circumstance" relevant to the offense or the defendant, the judge may impose a sentence up to one-third above the basic sentence. ${ }^{14}$ Thus, in New Mexico, the basic sentence, although a single term, acts as the effective maximum sentence a defendant may receive absent a judicial finding of an aggravating circumstance.

Alaska, Arizona, California, Indiana, New Jersey, and Ohio use different terminology for the "basic sentences" and "aggravating circumstances" they rely on, but to the same effect. In Ohio, for example, statutes require the court to impose the "shortest prison term authorized for the offense" unless the judge finds that the shortest prison term will "demean the seriousness" of the offender's conduct 
or "not adequately protect the public;" in such cases the judge may impose any term up to the statutory maximum. ${ }^{15}$ In California, statutes prescribe a "lower," "middle," and "upper" term for each offense and require a judge to impose the middle term absent a finding of "aggravating circumstances." 16 In Colorado, on the other hand, statutes set a fairly wide "presumptive range" for each offense class and require the court to impose a definite sentence within the presumptive range unless it concludes that "extraordinary aggravating circumstances" are present and support a different sentence that "better serves the purposes" of the criminal code. If the judge finds such circumstances, the judge may impose a sentence up to twice the maximum authorized in the presumptive range for the offense. ${ }^{17}$

As with the presumptive guidelines jurisdictions, these states share the common problem that a jury verdict, or guilty plea, only authorizes a sentence to the presumptive term or within the presumptive range. Any enhanced sentence relies on judicial fact-finding in violation of the Blakely rule.

\section{Voluntary sentencing systems}

In contrast with states that use presumptive sentencing systems, with or without guidelines, Io jurisdictions employ voluntary guidelines systems. These systems are similar in structure to the Washington guidelines in that they prescribe a range of sentences for each offense or offense class, but they differ in that the ranges are expressly not binding. Because there is considerable variety in the structure of these systems and differences in how legislatures instruct judges to employ the guidelines, some states may be at greater risk to Blakely challenge than others. These ro jurisdictions fall into two basic groups.

In four of these systems-those of the District of Columbia, Louisiana, Missouri, and Wisconsin-judges are encouraged to consider guidelines ranges in determining appropriate sentences, but no additional fact-finding is required of a judge to impose a sentence outside the range and up to the statutory maximum. Nor is there a requirement that judges provide reasons for doing so. In these four jurisdictions, the effective maximum sentence-that which is authorized by the jury verdict or a defendant's guilty plea-is the statutory maximum in all cases; thus they do not seem to conflict with Blakely.

The other six voluntary guidelines states-Arkansas, Delaware, Maryland, Rhode Island, Utah, and Virginia-may, however, run afoul of Blakely. They require judges first to apply the guidelines ranges but then allow them to depart upward-provided they state their reasons for doing so. In Arkansas, for example, "the presumptive sentence" in all cases is determined according to sentencing guidelines; for the judge to impose a sentence that varies more than five percent from the presumptive sentence, written justification "specifying the reasons for such departure" must be given. ${ }^{18}$ Similarly, in Virginia the judge must "review and consider" the suitability of the applicable "discretionary" sentencing guidelines. Before imposing sentence, the judge "shall state for the record" that such review and consideration have been accomplished. If the judge imposes a sentence greater than that indicated by the guidelines, the judge must file a "written explanation of such departure."19

The requirement in each jurisdiction that a judge first apply the sentences articulated in the guidelines and then provide reasons for a decision not to follow them may bring them within the Blakely rule. Put another way, the requirement that a judge state reasons as a pre-condition of an enhanced sentence may establish the top of the guidelines range as the effective maximum sentence-a situation no different from the one presented in Blakely. Whether this is so will have to be determined first by the courts through their interpretations of the practical effect of the state's specific statutory or administrative language. If a court holds that the practical effect of a state's system is that a judge cannot deliver an enhanced sentence absent the finding and stating of reasons beyond those found by a jury or admitted by a defendant, these systems may fall. ${ }^{20}$

Such a result is far from certain for the following reasons. One could argue that the advisory character of the systems in these five states would spare them Blakely problems; judges are expressly not required to follow the guidelines recommendations. A court could hold, therefore, that the requirement that judges apply the guidelines and provide reasons for departing does not in fact constrain a judge's discretion but serves solely as an information-recording function. Or it could determine that the requirement that reasons be provided is so flexible-allowing a statement to the effect of "the guidelines range is not adequate for this offense" - that the jury verdict or plea alone authorizes a sentence up to the statutory maximum. In such instances, these states may indeed be immune to Blakely. That said, there is adequate reason for caution. ${ }^{21}$ The Court made clear that the practical effects of sentencing rules determine the scope of the right to trial by jury, whether a system is called voluntary or not. ${ }^{22}$

\section{Presumptive sentencing guidelines in indeterminate systems}

Two states-Michigan and Pennsylvania—are in a somewhat different situation and it is less clear whether Blakely will affect them. Indeed, it is possible to construct equally compelling arguments that Blakely does or does not apply. 
The arguments turn on competing definitions of the effective maximum sentence in such indeterminate states.

Michigan and Pennsylvania employ indeterminate sentencing schemes with presumptive guidelines. ${ }^{23}$ In both states, judges set a minimum and maximum term to each sentence, but limits are imposed only on the setting of the minimum term. The maximum term may be set in all instances up to the statutory maximum. The minimum term determines a defendant's parole eligibility date, or the period a defendant must serve in prison; the maximum term controls a defendant's mandatory release date, or the maximum period a defendant will serve if not released by a parole board. Thus, in each state, the judge determines how long an offender must serve in prison before being eligible for parole release. The sentencing guidelines in these states establish a range of minimum terms. A judge may impose a minimum term above the guidelines range only by finding aggravating factors on the record.

The Court has previously held that the Sixth Amendment is not violated by a system that requires an enhanced minimum sentence based upon judicial findings of fact. Yet that ruling applies only so long as the enhanced minimum sentence is not beyond that "authorized by the jury's verdict." ${ }^{24}$

On the one hand, therefore, it may be argued that a sentence with an enhanced minimum term in Michigan and Pennsylvania effectively exceeds that authorized by the jury verdict because a defendant who receives such a sentence likely will remain incarcerated longer than one who receives a sentence with a minimum term within the guidelines range. To the extent that an enhanced minimum term - that is, one beyond the guidelines range-leads to a longer period of incarceration by extending the date at which the defendant is eligible to be released, these systems may be held to violate Blakely.

On the other hand, it is also possible to characterize the maximum sentence authorized by the jury verdict as being controlled solely by the maximum term in an indeterminate system, and there is no limit on the maximum term a judge may set in these two states up to the statutory maximum. Moreover, because of the discretion vested in the parole board - the hallmark of indeterminate sentencing-some who are given non-enhanced minimum terms may remain incarcerated longer than those sentenced to enhanced minimum terms; the minimum term only commences parole eligibility but does not require that a defendant be released on that date. Thus, to the extent it is determined that the effective maximum sentence is the statutory maximum or that the mere likelihood of an increased period of incarceration is not sufficient to trigger the jury right, these systems will be upheld.
Part of the difficulty in assessing the effect of Blakely is that it addressed a determinate sentencing structure-one without parole or other discretionary release-in which the sentence is expressed as a single term that fully determines when a defendant will be released. No decision in the Apprendi ${ }^{25}$ line has explicitly addressed the effect of these rulings on indeterminate sentencing structures such as in Michigan and Pennsylvania. ${ }^{26}$ Future rulings will be required to settle how, or if, Blakely applies to these states. ${ }^{27}$

There is, finally, one other group of states that this decision affects. A number of jurisdictions (some of which have already been discussed as implicated by Blakely) are currently revising their sentencing systems or criminal codes, or studying the need to do so. They include Alabama, Georgia, Indiana, Iowa, Maine, Nebraska, New Jersey, New Mexico, Vermont, and Wisconsin. Blakely's ultimate effects should significantly influence the manner in which they pursue reforms.

\section{Reconciling State Sentencing Systems with Blakely}

The dissenting opinions in the Blakely case were short on constitutional argument and long on discussion of the dire practical considerations for state sentencing systems. This is not surprising; the constitutional issue had been largely decided in the Court's prior rulings, and the implications for many states, as well as the federal system, are indeed enormous. But will they be as dire as predicted?

Before venturing an answer, it is important to note that, constitutional jurisprudence aside, the Blakely decision allows for some seemingly perverse effects. For example, in a sentencing system that fully relies on statutory minimum and maximum sentences, judges have the fact-finding authority necessary to determine the appropriate sentence anywhere within the statutory range up to the maximum in any given case. ${ }^{28}$ In such a system a judge may be authorized to make a fact-finding of deliberate cruelty, for example, and sentence a defendant to three years more incarceration than the judge might have otherwise. Yet a state is no longer free to do precisely that if it imposes limits on judicial sentencing discretion, as Washington did by enacting guidelines that regulate maximum sentences short of the statutory maximum. Thus the states may achieve in one context what the Court says the Constitution prohibits in another. It is perhaps perverse that the scope of the right to trial by jury turns on such a distinction.

Such effects notwithstanding, the Court's ruling does not require states to abandon their guidelines systems- 


\section{Managing a Response to Blakely}

Kansas shows that states can create effective and wellinformed processes to respond to Blakely. Following the Supreme Court's 2000 Apprendi ruling, Kansas officials were concerned about the constitutionality of their presumptive guidelines system. Even before the state's high court later validated that concern, the Kansas Sentencing Commission created a subcommittee to study the applicability of the ruling and to consider policy responses. Importantly, the subcommittee included legislators, prosecutors, defense attorneys, and judges. The participation of all four of these groups was essential to the creation of a legislative response that was not only substantively workable and fair but politically acceptable.

\section{As the group came to understand the Court's decision} and to consider which legislative options were most appropriate, subcommittee members kept the following key questions in mind, according to Barbara Tombs, then executive director of the Commission:

- First, what are the underlying goals of sentencing guidelines? Are principles of fairness, public safety, and resource control served by a possible solution?

- Second, how are the burdens of a possible solution distributed? Does either the defense or prosecution enjoy an unfair advantage or suffer an undue burden as a result? Are these factors in balance?

- Third, how does a solution affect judicial discretion and resources? Does a solution fit within understood or articulated powers granted to the court? And is it a solution that a court can apply with its existing capacity?

Thoughtful deliberations guided by these questions and participation by necessary institutional actors from both sides of the adversarial system and all three branches of government led to the creation of a legislative response that was quickly embraced and has proven to be effective in practice. although it certainly limits a state's avenues to channel judicial discretion. States that have chosen to rein in judicial discretion through the presumptive or voluntary systems affected by Blakely still have an option that retains the core of their systems and complies with the ruling. Those states can allocate fact-finding to juries when enhanced sentences are sought. States that seek to maintain a maximum of judicial sentencing authority while providing persuasive, although non-binding, guidance may seek to make their voluntary systems fully voluntary-like those in the District of Columbia, Louisiana, Missouri, and Wisconsin-if the courts hold that they currently are not so. And the imperative of revisiting current systems also may provide an opportunity for some states to move from a presumptive system to a voluntary one, or vice versa. The decision each state makes likely will turn on the goals it sought to achieve by enacting guidelines, the degree to which those goals remain vital, and the combustible political forces that exert themselves whenever criminal justice is the subject of reform.

\section{The feasibility of jury fact-finding}

After the Kansas Supreme Court invalidated the state's guidelines system in 200I (presaging Blakely), the legislature chose to retain presumptive guidelines by incorporating jury fact-finding as the basis of an enhanced sentence. ${ }^{29}$ Kansas's choice and its subsequent experience thus provide some guidance for states that must alter their systems. Under the revised system, if Kansas prosecutors decide to seek an enhanced sentence, they must file a motion 30 days before trial. The judge then decides whether, in the interests of justice, the evidence of enhancing factors must be presented at a post-trial sentencing hearing rather than at the trial. ${ }^{30}$ Only evidence that has been disclosed to the defense is admissible in an enhancement determination; if the defendant testifies at such a hearing it is not admissible in any subsequent criminal proceeding. The jury must be unanimous that a factor has been proven beyond a reasonable doubt. If the jury finds such a factor, the judge nonetheless retains the discretion to sentence within or beyond the guidelines range.

Neither prosecutors nor the defense bar have raised strong concerns about the justice or efficiency of this procedure. The Kansas Appellate Defender Office amicus brief in Blakely, arguing against the constitutionality of presumptive systems such as Washington's and Kansas's former system, provides implicit support for the state's legislative response. Interviews with defenders in the state indicate that the defense bar generally finds the procedure unobjectionable with one exception: the possibility that prejudicial "sentencing factors" might be presented during the trial (which appears not to 
have occurred to date). Interviews with prosecutors and judges in the state also indicate that the procedure does not place significant extra burdens on the system. It has been used infrequently, but not because it is unworkable. Indeed, it had always been rare for judges to sentence defendants to enhanced sentences after trial, largely because in a pleadriven system the available sentences after trial are already effectively "enhanced." 31

It is perhaps not surprising that jury fact-finding has proved feasible in Kansas. It is common in parts of other states' systems. Although not a structured sentencing state, Illinois previously authorized extended sentences based on judicially-determined facts. Following the Supreme Court's ruling in Apprendi, Illinois changed its enhancement statute to require that an aggravating factor be included in the charging document and that it be proved to the jury beyond a reasonable doubt. ${ }^{32}$ Although California employs a general presumptive system in which judges make fact findings necessary to depart from presumptive sentences, implicating Blakely, in other circumstances it requires that aggravating factors-such as possession of a weapon in the course of an enumerated offense-be put to a jury. ${ }^{33}$

It also has to be kept in mind that concerns voiced by a number of commentators regarding the workability of

The hope is that Blakely provides as much an opportunity as it does a challenge and that legislators will develop different and better approaches ...

jury fact-finding have a limited reach. The vast majority of criminal cases, perhaps as high as 95 percent, do not result in trials, ${ }^{34}$ and it appears that most guidelines states use enhanced sentences in only between two percent and nine percent of all cases. ${ }^{35}$ As with Kansas, Blakely affects only a small subset of trial cases that result in enhanced sentences, and trial cases themselves are only a small subset of all felony cases. Of course, the Blakely ruling may very well have some tangential effect on cases that result in pleas. The bargaining powers of prosecution and defense may shift, although it is far from clear in what direction, and the reports from Kansas are inconclusive in this regard. To the extent that the number of trials in the criminal justice system has diminished, the consequences of requiring juries to determine sentencing factors for enhanced sentences are relatively modest.

On the other hand, there are two ways — not present in Kansas-in which jury fact-finding of aggravating factors may lead to "significant administrative difficulties," as the federal government's Blakely brief puts it. ${ }^{36}$ First, in systems that use a large number of judicially-determined factors in arriving at the initial presumptive range-such as the federal systemjury fact-finding would have to be employed in virtually every sentencing, not just those in which an enhanced sentence was sought. It appears, however, that no state system relies on factors that determine the presumptive range to a degree comparable to the federal system. ${ }^{37}$ Second, in states that require prosecution by grand jury indictment there may be the significant additional burden of presenting "sentencing factors" for grand jury consideration at the outset of virtually every felony case to enable their later presentation to the trial jury. ${ }^{38}$

\section{Fully voluntary guidelines}

Some states, particularly those with voluntary systems that are deemed to be affected by Blakely, may choose not to follow Kansas's example of requiring juries to make such fact findings. Rather they may choose to eliminate their effective sentencing thresholds and adopt fully voluntary sentencing systems. Here, too, there are examples from which states may draw lessons. The District of Columbia, Louisiana, Missouri, and Wisconsin have enacted such fully voluntary systems.

Presumably they did so to achieve a proper balance between judicial discretion and legislative or administrative control so that sentences are geographically and racially neutral and appropriate to the offense.

To make their systems fully voluntary, these states might eliminate the requirement that judges provide reasons as a prerequisite to an enhanced sentence. Such a change is not, of course, without consequences and again suggests an apparently perverse result of the Blakely ruling. The requirement that judges provide reasons for departures would seem to be based on a state's determination of the value of publicly stating those reasons. Few would disagree that there is inherent value in requiring government actors to explain publicly decisions that have important individual and societal effects. And a state seeking to understand the causes of racial or geographic disparities in sentencing, for example, might examine the reasons stated in cases where members of different groups are given enhanced sentences. Moreover, although there is generally no right to appeal a sentence simply because it falls beyond the voluntary guidelines, appellate courts might in the future perform a rudimentary reasonableness review of all sentences, and this review would rely on sentencing judges' statements of their reasons. A regime that discourages the stating of reasons may adversely affect such appellate review of the reasonableness of sentencing decisions. 


\section{Questions to consider.}

In deciding how to fashion a cure to a state's Blakely ills, there are a number of questions each state may wish to consider to ensure that the cure is not worse than the disease. A state may consider the following in light of the goals that underlie its decision to enact structured sentencing:

- How will a chosen system affect the balance of power between the defense and the prosecution, especially in regard to its effects on the system of plea bargaining?

- How will it affect the ability of judges to incorporate sentencing factors relevant to the specific circumstances of the offense and specific history and circumstances of the defendant?

- How will it affect racial and other demographic disparities in sentencing?

- How will it affect geographic disparities; will like cases be treated more alike or less alike in different parts of the state?

- How will it affect average sentence lengths and, thus, prison populations?

- What effects will it have on the predictability of sentences for purposes of determining institutional resources, such as probation and corrections staff and facilities?

Voluntary states affected by Blakely have another option, however, for achieving fully voluntary systems. They can retain the general requirement that judges provide reasons for their sentencing decisions but make explicit that judges need only consider, but need not apply, the guidelines in any given case. Although this distinction may seem to split hairs, the Supreme Court's bright-line rule requires that hairs be split somewhere, and this seems a likely place. In this way the value of judicially stated reasons is preserved, but because application of the guidelines is truly voluntary the effective maximum sentence in each case is the statutory maximum and no Blakely problem arises. The nation's most recently implemented sentencing guidelines system-in the District of Columbia-has taken this approach.

The District expressly allows for sentencing outside the guidelines box based upon a "decision by a judge not to use the sentencing guidelines." ${ }^{39}$ It was a conscious decision of the District's sentencing commission to provide judges with the information that advisory guidelines offer but to allow judges to continue to sentence according to their own processes. The system also preserves the benefits of judicially stated sentencing reasons - it requires stated reasons in all cases, whether judges apply the guidelines or not-and the commission hopes to use information both from judges who use the guidelines and those who do not in fashioning future changes to the system.

\section{Other possible options}

Justice Breyer, in his Blakely dissent, mentions other possible options for states. One is an outright bar on judicial discretion through what he calls "determinate sentencing": mandatory terms or ranges of terms from which a judge may not depart. There is one state example of this approach in the non-guidelines context. Iowa uses a mandatory system in which judges are bound to impose the sole statutory term of years for most felony offenses and the parole board has discretion to determine how long the defendant ultimately will serve. But, in the guidelines context, it appears that no state uses a system that is fully mandatory. Other than Iowa, the states shy away from such extreme limits on judicial sentencing discretion.

Another of Justice Breyer's options is a retreat from guidelines altogether, to the indeterminate sentencing regimes used in roughly half the states. But given the caution and discernable lack of appetite to abolish guidelines systems that many state officials have shown in the weeks since Blakely, there is little reason to suspect that states will jettison their guidelines altogether rather than apply one of the modifications mentioned above.

Justice Breyer suggests, too, that there may be more threatening responses to Blakely, such as a top-down system in which the presumptive sentence for each offense would be the maximum sentence authorized by statute. A sentencing judge might then depart downward only after finding mitigating facts. Yet, there is no reason to believe this option will prove attractive to state policymakers as it would be costly and might lead to harsh, perhaps unpredictable, sentences. More realistic may be an option that Florida has chosen, in which a judge's ability to sentence at the top of the statutory 
range is not constrained. Yet, those states that enacted guidelines to control sentences deemed excessive may not be satisfied with such an approach. For such states the cost of jury fact-finding, as in Kansas, may be in line with the benefits of maintaining presumptive sentence ranges.

\section{$\cdots \cdots \cdots$}

The Supreme Court's decision in Blakely is not surprising from a legal standpoint in that it did not stray far from prior decisions. But it is truly extraordinary when viewed in the context of its near and far term implications for state sentencing systems. We have attempted one view of those likely implications, but this story is only beginning to play out. How courts will interpret different systems in light of Blakely is largely unknown and will guide legislatures in crafting new systems that preserve a reinvigorated right to trial by jury while also preserving to the greatest extent possible the goals of their structured sentencing systems. The hope is that Blakely provides as much an opportunity as it does a challenge and that legislators will develop different and better approaches than those we have mentioned.

To place in context the burdens state legislatures now face, Justice Scalia's closing words regarding Mr. Blakely's enhanced sentence serve as a useful reminder of what is at stake:

The Framers would not have thought it too much to demand that, before depriving a man of three more years of his liberty, the State should suffer the modest inconvenience of submitting its accusation to the unanimous suffrage of twelve of his equals and neighbours, rather than a lone employee of the State. ${ }^{40}$

\section{Notes}

${ }^{1}$ Blakely v. Washington, 542 U.S. ___ ; No. $02-1632$ (June 24, 2004) slip op. at 7 (emphasis in original).

${ }^{2}$ This examination focuses solely on the effects of Blakely on state sentencing structures. It does not address the ruling's significant impact on the federal sentencing structure.

${ }^{3}$ As discussed below, Kansas's system is not generally implicated by Blakely.

${ }^{4}$ Rhode Island does not have a guidelines system per se. Rather, it employs "sentencing benchmarks" similar to the other five states mentioned here, established by court rule.

${ }^{5}$ In this paper we use "structured sentencing systems" to refer to sentencing guidelines, whether labeled presumptive or voluntary, as well as to other comprehensive systems of presumptive sentences.

${ }^{6}$ Blakely, slip op. at 13 (O'Connor, J., dissenting).
${ }^{7}$ Blakely, slip op. at 12 (internal quotation marks omitted). The Court uses the term "determinate sentencing" in the same way we use "structured sentencing."

${ }^{8}$ Id. at 18 .

${ }^{9}$ Wash. Rev. Code 『 9.94A.535, 539.

${ }^{10}$ N.C. Gen. Stat. $\int 15 A-1340.13$.

${ }^{11}$ Tenn. Code Ann. \ 40-35-210.

${ }^{12}$ State v. Gould, 23 P.3d 801 (Kan. 2001).

${ }^{13}$ The Kansas Supreme Court, however, subsequently limited its holding to upward durational departures, finding upward dispositional departures not to be implicated by Blakely's antecedents. For the reasons that will be stated in the companion report, Legal Considerations for State Sentencing Systems, it is doubtful that this distinction will stand; Kansas too therefore may be affected by Blakely.

${ }^{14}$ N.M. Stat. Ann. $\int 31-18-15(B), 15.1$.

15 Ohio Rev. Code Ann. \2929.14(C).

${ }^{16}$ Cal. Penal Code $\int 1170$.

${ }^{17}$ Colo. Rev. Stat. $\int 18-1.3-401$.

${ }^{18}$ Ark. Code. Ann. \$16-90-803, 804.

${ }^{19}$ Va. Code Ann. \19.2-298.01 (A), (B). Arkansas and Virginia both rely on jury sentencing for all cases tried before a jury. In such cases, the jury is free to select any sentence within the statutory sentence range and is not in any way required to base the sentence on the sentencing guidelines. In such jury-sentencings, no Blakely issue is raised. However, the judge determines the sentence in any case where: the defendant pleads guilty to an offense; the defendant waives a jury trial and is tried by the court; the jury does not unanimously agree on the sentence; or the prosecution and the defense agree that the court may fix punishment. In such cases, the court must apply the sentencing guidelines and provide justification for an enhanced sentence.

${ }^{20}$ Louisiana provides an example of a state whose guidelines were labeled as voluntary but found by the courts to be presumptive because judges were required to apply them and provide reasons for departing from the recommended range.

${ }^{21}$ See the companion report, Legal Considerations, for a fuller discussion of the Court's reasoning and its implications.

${ }^{22}$ There is yet one further distinction that might insulate three of the voluntary guidelines systems from Blakely in the event that they are deemed to be within its ambit. Arkansas, Delaware, and Virginia statutorily require judges to provide reasons for a sentence beyond the guidelines range. In Maryland, Rhode Island, and Utah, on the other hand, sentencing commission policy or court rule, rather than statute, provides the source of the legal rule that requires reasons to be stated for a sentence above the guidelines recommendation. Md. Regs Code, 14 \22.01.05; Utah Code Jud. Admin., App. D: R.I. Rules of Court, Superior Court Sentencing Benchmarks. However, as will be discussed in Legal Considerations, to the extent that such administrative rules have the force of law it is likely that this distinction ultimately will be found immaterial under the Court's reasoning.

${ }^{23}$ Additionally, Florida, which has determinate sentences expressed 
as a single term, employs a system that provides a presumptive minimum sentence for each offense/criminal history score. It is thus rather like one-half of a presumptive guidelines system. The sentencing court may sentence the defendant to any sentence at or above the designated minimum up to the statutory maximum. Because there is no constraint on a judge's sentencing decision above the presumptive minimum, the sentence authorized by the jury verdict or plea is always the statutory maximum, to which a judge may sentence any defendant. The only constraint is on sentences below the mimumum, for which the judge must provide reasons. Such a system is in no way implicated by Blakely.

${ }^{24}$ Harris v. United States 536 U.S. 545 (2002) at 567. For further discussion of Harris, see Legal Considerations.

${ }^{25}$ Apprendi v. New Jersey, 530 U.S. 466 (2000), was the first definitive statement governing the Sixth Amendment's jury right as it applies to the finding of facts relevant to enhanced sentences.

${ }^{26}$ In a footnote, the Michigan Supreme Court has noted that Blakely "did not affect indeterminate sentencing systems," such as Michigan's. People v. Claypool, No. 122696 (Mich., July 22, 2004), slip op. at 17, n.14. In response, the Chief Justice stated: "Given the lack of any definitive statement by the United States Supreme Court regarding mandatory minimum sentences, I believe that sweeping statements of broad judicial authority ... may serve only to borrow trouble." Slip op. at 11 (Corrigan, C.J., concurring in part and dissenting in part).

${ }^{27}$ One other state, New Jersey, has a provision adjunct to its basic presumptive sentencing structure whereby judges may, upon the judicial finding of aggravating factors, set a minimum term that increases the likelihood that a defendant will remain incarcerated longer than otherwise. New Jersey uses an indeterminate system in which judges set a maximum term for each sentence; the minimum term for each sentence is one-third of the maximum imposed by the court. Yet, upon the finding that "aggravating factors substantially outweigh the mitigating factors" a judge may set a minimum term that is one-half of the maximum term imposed. N.J. Stat. Ann. $\int_{2} \mathrm{C}: 43-6$ (b). This minimum term extends the defendant's parole eligibility date from the typical one-third to what is effectively one-half of the maximum term. Just as in Michigan and Pennsylvania, therefore, defendants sentenced to enhanced minimum terms may remain incarcerated for longer than they would have in the absence of the judicial finding of aggravating factors.
${ }^{28}$ There is a constitutional limit on what the state can choose to label a sentencing factor and thus allocate to judicial fact-finding, and what to label an element and leave to juries to determine, but states have wide discretion in this area and there is no bright-line rule to help in drawing the line. See Blakely, slip op. at 6, n. 6 .

${ }^{29}$ Kan. Stat. Ann. $\int 21-4718$ (b).

${ }^{30}$ Justices Breyer and O'Connor note in their Blakely dissents the problem of character and other evidence not strictly relevant to the charge prejudicing a jury in its determination of guilt, thus necessitating a separate post-trial sentencing hearing in some instances. Slip op. at 8 (Breyer, J., dissenting) and 6 (O'Connor, J., dissenting).

${ }^{31}$ Indeed, in the four years before the new procedure took effect, there were never more than 24 jury trial cases in the state that led to enhanced sentences. Figures compiled by the Kansas Sentencing Commission, provided by e-mail correspondence.

32725 III. Comp. Stat. 5/111-3(c-5).

${ }^{33}$ See, for example, Cal. Penal Code $\$ 12022.53$.

${ }^{34}$ In 2000, 95 percent of all felony convictions in state courts followed a guilty plea, three percent followed a jury trial, and two percent a bench trial. Matthew R. Durose and Patrick A. Langan, State Court Sentencing of Convicted Felons, 2000 Statistical Tables. (Washington, DC: Department of Justice, Bureau of Justice Statistics, June 2003) Tables 4.1 and 4.2.

${ }^{35}$ Brian J. Ostrom, Neal B. Krauder, David Rottman, and Meredith Peterson (1998), Sentencing Digest: Examining Current Sentencing Issues and Policies (Williamsburg, VA: National Center for State Courts) at 13 .

${ }^{36}$ Brief for the United States at 31.

${ }^{37}$ This problem will be discussed in Legal Considerations.

${ }^{38}$ Eleven states and the District of Columbia require grand jury indictments of felony charges, five of which are among those we conclude are possibly affected by Blakely.

${ }^{39}$ Practice Manual, Superior Court of the District of Columbia Voluntary Sentencing Guidelines, ch. 5.

40 Blakely, slip op. at 13 (internal quotation marks and citation omitted).

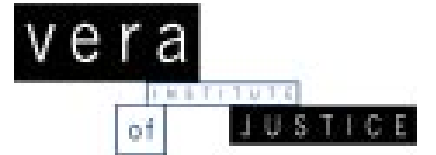

(C) Vera Institute of Justice, 2004. All rights reserved. Publication of this report was supported by a grant from the JEHT Foundation. Unattributed points of view are those of the authors and do not represent the position or policies of the JEHT Foundation. We offer our thanks to Nomi Maeyama of the Vera Institute and to interns David Gopstein of Princeton University and Katherin Slimak of Tulane Law School for their tenacious efforts to keep abreast of the many Blakely twists and turns in the weeks after the decision.

The Vera Institute of Justice is a private, nonprofit organization dedicated to making government policies and practices fairer, more humane, and more efficient. Working in collaboration with public officials and communities in the United States and throughout the world, Vera designs and implements innovative programs that expand the provision of justice and improve the quality of life. The State Sentencing and Corrections Program is one of several national peer-to-peer consulting and technical assistance initiatives Vera operates. 